\title{
射出保圧の多段制御について 再計量式保圧室射出成形法
}

\section{1.はじめに}

射出成形の発達を 80 年位前からたどってみると, その目的は，「ハイサイクル成形」と「精密成形」の 2 つの項目であり，その改良の歷史であったと集約でき る.この方向は今も続いて扣り，その最も大きな流れ は, 20 年ほど前に起きたコンピュータ搭載による射出 保圧の多段制御技術の普遍化であって, 今や 10 段に も達している. しかし, ハイサイクル成形に関しては 1サイクル何秒という数值で比較評価ができるが，一 方, 精密成形に関しては厳然たる評価基準といらもの がなく共通のものさしで比較されるということは，法 とんどなかった。

そこで筆者は,「精密成形」を考える時に，まず基準 となるものさしを決める必要があると考えた，その評 価基準となるものさしを品質管理に秥いて一般に知ら れている変動係数 $\sigma / \bar{x}$ を使い, 3 倍値をとって $3 C$ と略称し, 精密成形の評価基準として $3 C$ を用いて比 較すべきであると考学る。

$$
3 C=(3 \sigma \mid \bar{x}) \times 100(\%)
$$

$\sigma:$ 標準偏差 $\quad \bar{x}: 1$ ショット重量の平均值

また, 変動係数 $(C)$ 治品質管理上の手法で, 精密 成形の評価基準のものさしとして採用し，以下この 3 $C$ を用いてデータに基づいて述べる.

筆者は昨年 8 月のプラスチック成形加工学会の第 1 回年次大会に沶いて，射出保圧の多段制御の排除につ いて，第 1 報「可塑化工程と射出保圧工程の同時化」 と題して発表した. その後, 実験を重ね, 第 2 回年次 大会に拈いて第 2 報「改良された再計量式保圧室射出 成形方法」として，データに基づいて発表した。

射出成形機の発達の経過をみると, ハイサイクル成

\footnotetext{
* Shigeru Tsutsumi

世紀工業(株)

米沢市万世町片子 4364 (勇 992-11)

1990.7.4 受理
}

堤

形と, 精密成形を別々の装置, 方法で対応してきたの が多い.

この 2 つの目的を同時に 1 つの方法, 1 つの装置で 達成できるようにしたのが，この「再計量式保圧室射 出成形方法」である.

この技術報告において，初めに述べておきたいこと は,すでに確立された理論としてまだ提供できないと いらことである. まず始めに，概念的に射出成形につ いて，基礎的なところで, 従来の考えとは全く異なる 立場に立ったので，まず概念の確立が優先させられた こと, その次の段階としてデータの蓄積と解析, 第 3 段階で理論化といらステップに入っていくものと理解 するけれども, 時あたかもプラスチック成形加工学会 の発足といらことがあって, 成形加工という学会の名 称が示すように, 成形加工の現場を重視する学問とい らように理解し, 保圧室といら概念は, 射出成形とい ら分野に打いて, 未踏の分野であり, 概念の確立とい うことを優先し, 学術的に未完成であるという状況に あることをまず断わりしておく.

筆者はをた, 成形加工業者として, 射出成形の発明 に従事しており, 学題分野を専門とする研究者ではな いので, 成形加工の現場から, 射出成形に再計量式保 圧室成形法の例に見られるような，単純にして大きな 末踏の分野が基礎的にまだ残っている面白さの意義を 学術的希望の広さとして認めていただければ幸甚であ る.

筆者はこれから第 3 報, 第 4 報, 第 5 報と継続して 順次データを整理しながら，困難な作業になるもの之 思らが, 保圧理論の解析に進んで行くつもりである.

\section{2. 改良された再計量式保圧室 成形方法の概要}

再計量保圧装置の概要は, 図 1 のように, 保圧室と バルブと再計量装置からなっている.

ノズルからゲートまでの間にキャビティ容積に対応 


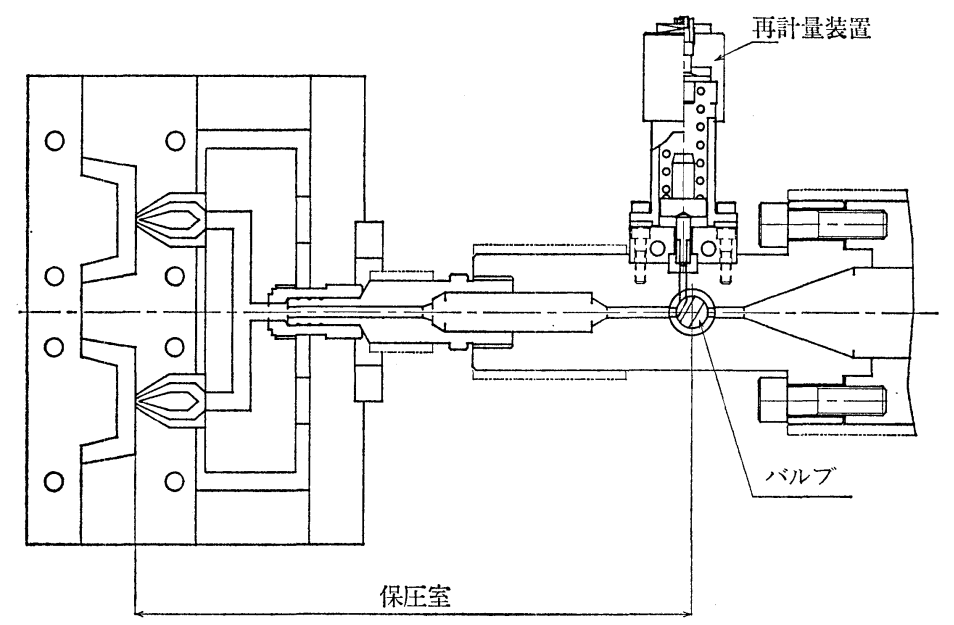

図 1 改良された再計量式保圧室成形装置
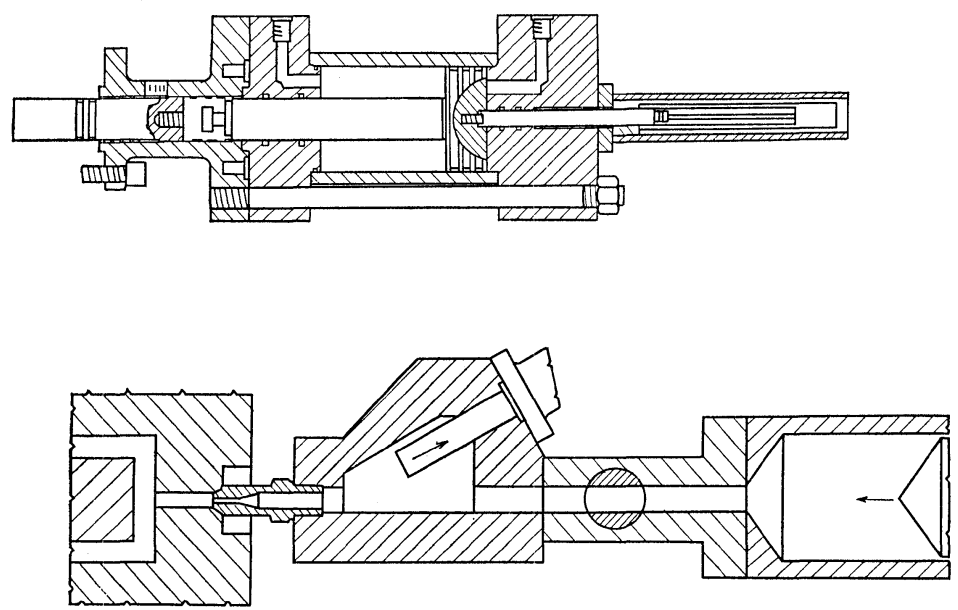

図 2 イタリアの先行技術

した容積を持つ保圧室を設け, 射出充媜後バルブを閉 ごることによって樹脂の流路を遮断し，保王室内に封 じ込められた圧縮された樹脂の残留内圧によって保圧 効果を発揮させる装置である.

従来はスクリュー先端に貯留された溶融樹脂をいか に精度良く計量するかが問題であって，精密成形の重 要な要素としてェンコーダー等で制御してきた。 しか し, 再計量式保圧室では，昔のりミットスイッチによ る単純計量でよい，二次的に保圧室の内圧を一定にす ることによって, 閉空間の溶融樹脂の重量を一定に計 量したことと同じ結果を与えるようにした，それで， 再計量式と呼ぶことにした. いわば，圧力一定化によ る計量である，そのために，保圧室の樹脂内圧の過䛢 分の溶融樹脂を射出成形のつど，バネ圧を利用した逆 止弁式弁支援装置を用いて系外に排除して $3 C$ をよ り小さく掠さえることにした.

筆者は, 支援装置に油圧ピストンを用いる圧力方法
はとらない，国際サーチの結果知られた図 2 亿例示し たような、イタリアの先行技術があるからという理由 だけではない，基本的に油圧によるピストン式では， 油圧が常に変動しているために, 閉空間が振動してお。 り閉空間を固定できないからである，それは $3 C$ を悪 くするはずである. 手間ヒマかけて $3 C$ を悪くする必 要はないといらわけである，支援装置に油圧を用いる のと逆止弁として作用するバネを用いるのとでは，少 ない分を，閉空間を振動させながら補助的に押し込め るのと，過剩分を系外に排除して閉空間を固定するこ ととの差であって，似ているけれども全くの逆作用で ある.

また，本装置は射出充填後，バルブを閉めることに より, 直ちに可塑計量が可能となるので, 従来の成形 方法に打ける多段保圧工程の時間を可塑計量の工程に 使用することができる．乙たがって，可塑計量の終了 を早め，成形サイクルの短縮ができる．理論的には， 
表 11 速 2 圧の旧式制御による測定データ

\begin{tabular}{ccccc}
\hline \multirow{2}{*}{$\begin{array}{c}\text { ショ数 } \\
n\end{array}$} & $\begin{array}{c}\text { 平均重量 } \\
\bar{x}(\mathrm{~g})\end{array}$ & $\begin{array}{c}\text { 標準偏差 } \\
\sigma(\mathrm{g})\end{array}$ & $\begin{array}{c}\text { Vソ } \\
R(\mathrm{~g})\end{array}$ & $\begin{array}{c}3 C \\
(\%)\end{array}$ \\
\hline 100 & 52.637 & 0.0185 & 0.083 & 0.105 \\
\hline
\end{tabular}

表 2 コンピュータ多段制御による測定データ

\begin{tabular}{ccccc}
\hline ショット数 & $\begin{array}{c}\text { 平均重量 } \\
\text { 標準偏差 } \\
\sigma(\mathrm{g})\end{array}$ & $\begin{array}{c}\text { レンジ } \\
R(\mathrm{~g})\end{array}$ & $\begin{array}{c}3 C \\
(\%)\end{array}$ \\
\hline 100 & 52.821 & 0.0203 & 0.095 & 0.115 \\
\hline
\end{tabular}

表 3 改良前保圧室装置による測定データ

\begin{tabular}{ccccc}
\hline \multirow{2}{*}{$\begin{array}{c}\text { ショト数平均重量 } \\
\bar{x}(\mathrm{~g})\end{array}$} & $\begin{array}{c}\text { 標準偏差 } \\
\sigma(\mathrm{g})\end{array}$ & $\begin{array}{c}\text { レソジ } \\
R(\mathrm{~g})\end{array}$ & $\begin{array}{c}3 C \\
(\%)\end{array}$ \\
\hline 50 & 52.774 & 0.0207 & 0.090 & 0.117 \\
\hline
\end{tabular}

これ以上成形サイクルを短縮することは不可能である といえる。

\section{3. 再計量式保圧室成形装置による効果}

再計量式保圧成形装置を使用し，いろいろな金型に て実験を行った結果, 次のような $3 C$ のデータが得ら れた。

【実験 1】 $\mathrm{A}$ 社の古いタイプの 1 速 2 圧の単純制御 の 150 トン射出成形機を朋い,オーディオカセットの スチロールケースの 4 個取り金型でホットランナーシ ステム（スピアシステム）によって成形した.

【実験 2】 B 社のコンピュータ搭載による多段制御 （8段）の新射出成形機によった。他の条件は実験 1 に同じ.

【実験 3】実験 1 で使用した 1 速 2 圧の単純制御の 150 トン射出成形機を用い, 同じオーディオカセット のスチロールケースの 4 個取り金型でスピアシステム によって成形を行った．保圧成形装置は，再計量を使 用していないすすなわち，保圧室の樹脂圧調整を行わ ない方式である.

表 2 のコンピュータ搭載による多段制御の新鋭機の $3 C=0.115 \%$ と比較して, 改良前の保圧室の $3 C=$ 0.117\% は汪とんど同じである. しかし，ハイサイク 儿性と長期成形の安定性と操作性（未熟練者で成形で きる）とコストの面で改良前であっても, 保圧室の方 がすでに優位である．第 1 報で報告した保圧室の概念 図は，図 3 である.

【実験 4】図 1 の再計量式保圧室成形装置を実験 1 で使用した成形機に搭載し，金型も同じオーディオカ セットのスチロールケースの 4 個取りである.

実験 $1,2,3$ と比較して初めて $3 C$ が 0.1 を割り 込んでいる. しかし，改良効果としてまだ不十分であ

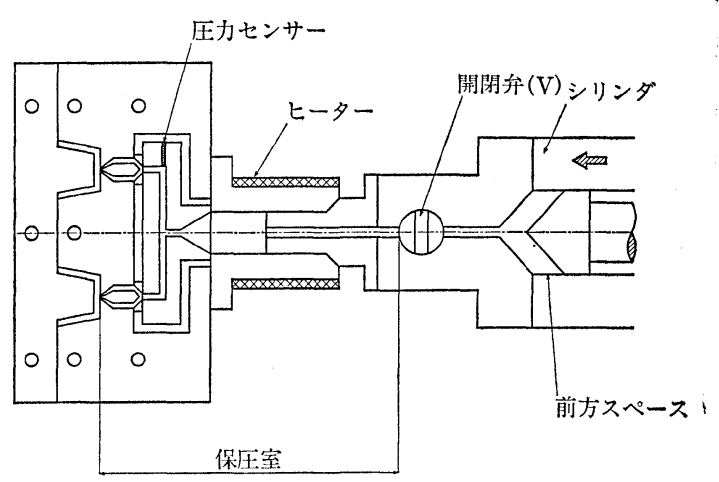

図 3 改良前の保圧室成形装置

表 4 再計量保圧装置による測定データ

\begin{tabular}{|c|c|c|c|c|c|}
\hline 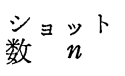 & $\begin{array}{l}\text { 平 均 } \\
\bar{x}(\mathrm{~g})\end{array}$ & $\begin{array}{c}\text { 標準偏差 } \\
\sigma(\mathrm{g})\end{array}$ & $\begin{array}{l}\text { レンジ } \\
R(\mathrm{~g})\end{array}$ & $\begin{array}{c}3 C \\
(\%)\end{array}$ & $\begin{array}{l}\text { 漏らし量 } \\
(\mathrm{g} / \mathrm{shot})\end{array}$ \\
\hline 50 & 52.672 & 0.0171 & 0.083 & 0.097 & 0.209 \\
\hline
\end{tabular}

表 5 成形現場での実際例

\begin{tabular}{|c|c|c|c|c|c|}
\hline & ショット数 & $\begin{array}{l}\text { 平均重量 } \\
\bar{x}(\mathrm{~g})\end{array}$ & $\begin{array}{c}\text { 標準偏差 } \\
\sigma(\mathrm{g})\end{array}$ & $\begin{array}{l}\text { レソ ジ } \\
R(\mathrm{~g})\end{array}$ & $\begin{array}{l}3 C \\
(\%)\end{array}$ \\
\hline (1) & 100 & 172.618 & 0.1165 & 0.611 & 0.202 \\
\hline (2) & 100 & 148.249 & 0.2675 & 1. 604 & 0.541 \\
\hline
\end{tabular}

注）(1)ロアケース（2)アッパーケース

る.きついけれども 0.05 ぐらいを超精密成形として 目指したい，方向としては，すでにその方向に入って いる. バネによる過剩圧の系外自動排除によって漏ら し量が出ている， $3 C$ を小さくすると相対的に漏らし 量が多くなるようだ。

【実験 5】成形現場では，多段制御の射出成形機に よって, 実際にはどの程度の $3 C$ で成形されているの か.ビデオカセットの 4 個取り成形品で金型はスピフ システムを組込んだホットランナー金型である。材料 はPS. 射出成形機はC 社の 220 トンの 8 段の多段制 御機である.

$3 C$ で $0.202 \%$ はまだしも， $0.541 \%$ のものでも良 品の範囲に入っている. 他の例でも成形現場では, 大 体 $0.2 \%$ 台で使用されているとみられる. $3 C$ の值が $0.2 \%$ 台では漏らし量を出す必要はない. $3 C$ を 0.1 以下に和さえる必要のある超精密成形の場合のみ必要 となる。

精密成形性評価を $3 C$ で行った. 技術史的な発展経 過の評価ともなっている．要約すると表 6 のと㧍りで ある.

以上実験 1 から実験 5 は，全てホットランナー金型 を使用しての実験結果であるが、コールドランナー金 
表 $63 C$ による総合評価

\begin{tabular}{|c|c|c|c|}
\hline $\begin{array}{l}\text { 実験 } \\
\text { No. }\end{array}$ & 実 験 内 容 & $3 C(\%)$ & $\begin{array}{l}\text { 精密成形 } \\
\text { の区分 }\end{array}$ \\
\hline \multicolumn{2}{|r|}{ 再計量保圧室 } & 0.097 & 成形 \\
\hline 1 & $\begin{array}{l}1 \text { 速 } 2 \text { 圧の旧式制御 } \\
\text { コンピュータ搭載による多 }\end{array}$ & & \multirow{3}{*}{ 精密成形 } \\
\hline 2 & 段制御 & $0.115\}$ & \\
\hline 3 & 改良前保圧室 & 0.11 & \\
\hline 5 & $\begin{array}{l}\text { 段制御の成 } \\
\text { 例 }\end{array}$ & & \\
\hline
\end{tabular}

表 7 コールドランナー金型における測定データ

平均重量 標準偏差 レンジ $3 C$ $\begin{array}{lll}\bar{x}(\mathrm{~g}) & \sigma(\mathrm{g}) & R(\mathrm{~g}) \quad(\%)\end{array}$

\begin{tabular}{llllll}
\hline 普 通 成 & 形 & 107.229 & 0.0487 & 0.203 & 0.136 \\
保 壬 室 成 形 & 106.812 & 0.0433 & 0.192 & 0.122 \\
再計量保圧室成形 & 106.665 & 0.0372 & 0.201 & 0.104
\end{tabular}

型に再計量式保圧室装置を使用した場合の効果につい て, 次の実験を行った.

実験の方法を次に示す。

（1）普通成形，保圧室成形に打いて，適切な成形 条件を見つけだし，それぞれの条件において普通成形 と保王成形を行い, 製品の重量測定により, 保圧室成 形の有效性を確かめる.

（2）再計量保圧室成形の有効性を確かめる.

【実験 6】コールドランナーの 2 個取りで成形品は $107 \mathrm{~g} / \mathrm{shot}$ のスケール(図 4)，3 mm でかなり肉厚の 成形品である.

$3 C$ で $0.104 \%$ は $3 \mathrm{~mm}$ の肉厚品であるのに超精密 成形に近い、コールドランナーにも再計量保圧成形は 有効である.

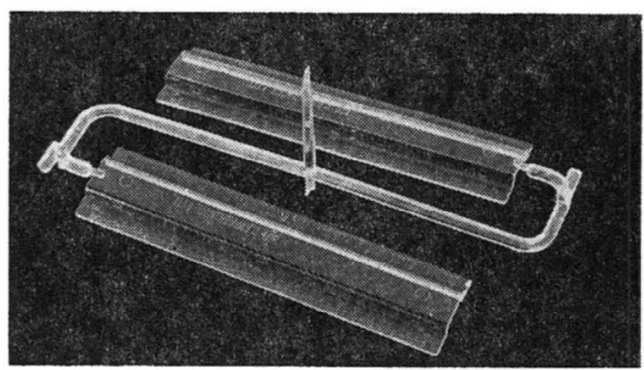

図 4 スケール

\section{4. 再計量式保圧室成形装置の特徵}

（1）再計量式保圧室装置により，射出成形のつ ぞ, 保圧を一定にすることが可能となり, 絶対比較値 $3 C$ の大幅な向上が図れる，したがって，本装置は図 1のよ5に単純な装置ではあるが, コンピュータ搭載 の射出成形機に劣らぬ成形ができる.

(2) 再計量式保生室装置のバルブ操作により, 保 圧中に可塑計量ができる.このことは, 保圧と可塑計 量の複合動作を可能とし, 成形サイクルの短縮への道 を開くものである. むた，可塑計量時間を長くとれる 効果もあり，このことがスクリュ一の混練効果の改善 に役立ち，スクリューの回転による分子切れを防止で きる。

（3）成形条件の設定に揖いて，複雑な多段制御の 設定に比へ，再計量装置の調整で凧み，最適条件の設 定が容易になる.

（4）本装置（図 5) は射出成形機のノズルのかわ りにシリンダーに取り付ける棰造になっている。 ほと んどの成形機に比較的容易に取り付けることができ る.

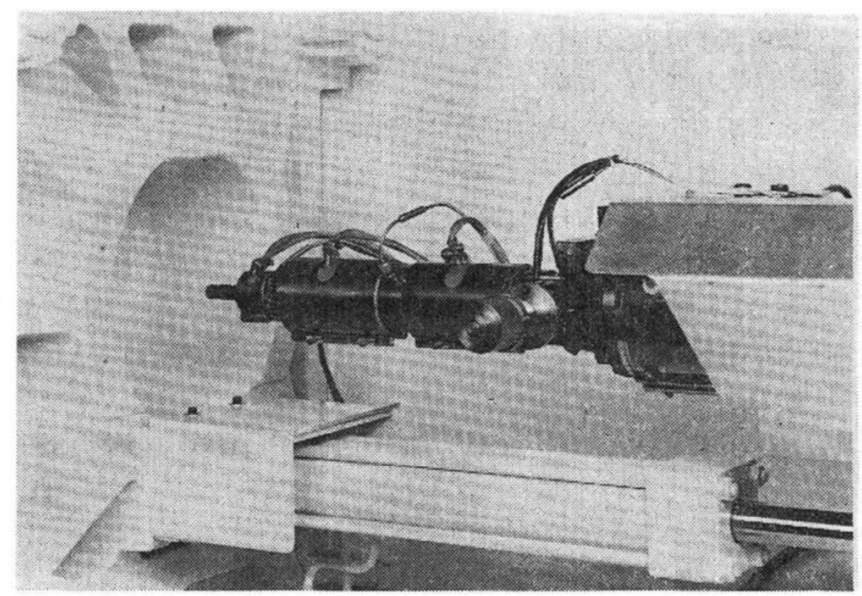

図 5 再計量保圧室成形装置 


\section{5. おわりに}

再計量式保圧室成形装置は未完の初期段階である. それでも精密成形々ハイサイクル成形の 2 項目をすで に満たしはじめて拉り，ら束く使える範囲が広がって いる. 保圧室容積のキャビティ容積に対する比の許容 度はかなりゆるやかである。
成形品ごとに保圧室を変光る必要は全くない，しか し, その理論は現状では解明されていない，思うに， 保圧室の中では 1 回叔きの時間差射出によって圧力, 温度, ひずみなどの平準化が起きており，これが $3 C$ を小さくしていると考光られる. 今後, $3 C$ では評価 できないレンズのひずみのない成形を行らなど実験を 重ね，本装置の完成度を高めていく所存である.

\section{茨城大学工学部機械工学科 教官公募。!}

公募人数 教授 1 名

所属 機械工学科 生産技術工学大講座

担当分野 機械工作学の分野 (切削・研削加工学, 特殊加工学, 生産システム 工学, 精密測定学, 形状計測学, 溶接工学, プラスチック加工学, 複合材料加工学, その他の材料加工学)

応募条件 上記分野において, 博士の学位を有し, 学部ならびに大学院の研究 の指導ならびに教育を担当するのに相当な業績，経歴を有する方 で, 年齢 55 歳以上の方

着任時期 平成 3 年 4 月 1 日

提出書類 (1) 履歴書 (写真添付), (2) 研究業績 (著書, 論文, 報告書等) のリスト，（3）主要論文別刷またはコピー

応募締切 平成 2 年 10 月末日

書類提出および問合せ先 $\bar{\top} 316$ 茨城県日立市中成沢町 4-12-1, 茨城大学工 学部機械工学科, 主任教授 大森宮次郎 電話 0294-35-6101, 内線 305 (大森), 351 (岡田養二) 